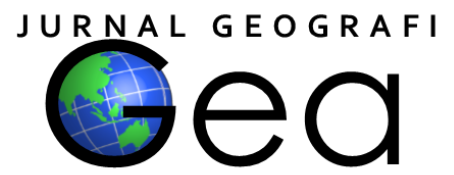

\title{
NILAI-NILAI KEBUDAYAAN DI KAMPUNG ADAT DUKUH SEBAGAI BENTUK KEARIFAN LOKAL HIDUP SELARAS DENGAN LINGKUNGAN
}

\author{
Ely Satiyasih Rosali ${ }^{1}$, Revi Mainaki ${ }^{2}$ \\ ${ }^{1,2}$ Jurusan Pendidikan Geografi, Fakultas Keguruan dan Ilmu Pendidikan \\ Universitas Siliwangi \\ 1ely@unsil.ac.id, ${ }^{2}$ revim63@gmail.com
}

\begin{abstract}
Indonesia is a country with a strategic location in which there is a pluralistic society, where each region has a culture in the form of positive values that form local wisdom as identity. One of them is in the Traditional Village of Hamlet which has a cultural value of life in harmony with the environment as a form of acculturation. In order to know the value of culture and the effort to maintain that value, research is carried out with a qualitative, descriptive method. Data is collected in the form of observations, literature studies, interviews and documentation studies from the local government, caretakers of traditional villages and local communities. The results of the study show the cultural values in the traditional villages including 1) Distribution of types of customary land;2) Forms of residences and 3) Local Universal Cultural Elements which are still maintained by means of 1) do not carry out trading activities in the Dukuh Dalam Village, 2) refuse to use electricity, 3) do not become Civil Servants and 4) stay alive in simplicity. Living in harmony with the environment will help prevent damage that has a negative impact on human life, so it needs the active role of the local government and the surrounding community in preserving the non-objects cultural heritage.
\end{abstract}

Keywords: Value, Culture, Local Wisdom

\begin{abstract}
ABSTRAK
Indonesia merupakan negara dengan letak strategis yang didalamnya terdapat masyarakat yang majemuk, dimana setiap wilayah memiliki kebudayaan yang berupa nilai positif sehingga membentuk kearifan lokal setempat sebagai identitas. Salah satunya terdapat di Kampung Adat Dukuh yang memiliki nilai kebudayaan hidup selaras dengan lingkungan sebagai bentuk akulturasi. Guna mengetahui nilai kebudayaan dan upaya mempertahankan nilai tersebut dilakukan penelitian dengan pendekatan kualitatif, metode deskriptif. Data dikumpulkan dalam bentuk observasi, studi pustaka, wawancara dan studi dokumentasi dari pemerintah setempat, juru kunci kampung adat dan masyarakat setempat. Hasil penelitian menunjukan nilai kebudayaan di kampung adat tersebut diantaranya 1) Pembagian jenis tanah adat; 2) Bentuk rumah tinggal dan 3) Unsur Budaya Universal lokal yang masih dipertahankan dengan cara 1) tidak melakukan aktivitas berdagang di lingkungan Kampung Dukuh Dalam, 2) menolak memanfaatkan aliran listrik, 3) tidak menjadi Pegawai Negeri Sipil dan 4) tetap hidup dalam kesederhanaan. Hidup selaras dengan lingkungan akan membantu mencegah kerusakan yang berdampak negatif bagi kehidupan manusia, sehingga perlu peran aktif pemerintah setempat dan masyarakat sekitar dalam melestarikan warisan nilai kebudayaan non benda tersebut.
\end{abstract}

Kata kunci: Nilai, Kebudayaan, Kearifan Lokal 


\section{PENDAHULUAN}

Indonesia yang berada diantara Benua Asia dan Australia, Samudra Pasifik dan Hindia membuatnya menjadi masyarakat yang majemuk, karena mendapatkan pengaruh dari multi negara akibat letaknya tersebut. Sisi majemuk tersebut salah satunya dari kebudayaan, yang menjadi identitas atau ciri dari setiap wilayah yang ada di Indonesia serta dapat dikatakan sebagai salah satu indikasi geografis dari suatu daerah, dimana kondisi fisik mempengaruhi pola, tingkah laku dan kebiasaan baik positif atau negatif sehingga menjelma menjadi nilai yang menjadi ciri khas. Hal tersebut terjadi karena kebudayaan bersumber dari pengalaman belajar setiap individu sebagai anggota masyarakat, maupun kebiasaan yang para leluhur yang diwariskan secara turun temurun.

Koentjaraningrat (1993: 25) menyatakan bahwasanya kebudayaan terdiri dari konsepsikonsepsi, yang hidup dalam alam pikiran sebagian besar warga masyarakat, mengenai hal-hal yang harus mereka anggap amat bernilai dalam hidup. Karena itu, suatu sistem nilai budaya biasanya berfungsi sebagai pedoman tertinggi bagi kelakuan manusia. Sistem-sistem tata kelakuan manusia lain yang tingkatnya lebih konkret, seperti aturan-aturan khusus, hukum dan norma-norma, semuanya juga berpedoman kepada sistem nilai budaya itu. Bentuk-bentuk tersebut menurut Sirtha dalam Sartini (2004: 112) yaitu nilai, norma, etika, kepercayaan, adat-istiadat, hukum adat dan aturan-aturan khusus.

Budaya merupakan satu dari beberapa unsur yang terdapat dalam kearifan lokal atau nilai positif berkehidupan dan berprilaku dalam masyarakat, masyarakat sendiri menurut Maclver (1955: 5) dalam Harsojo (1984: 127) merupakan sistem dari cara kerja dan prosedur, dari otoritas dan saling bantumembantu yang meliputi kelompok-kelompok dan pembagian sosial lain, sistem dari pengawasan tingkah laku manusia dan kebebasan, dalam sistem tersebut perlu aturan yang tidak tertulis akan tetapi ditaati dan dijadikan pedoman dalam bermasyarakat tersebut, yang dikenal dengan istilah kearifan lokal.

Ernawi dalam Wikantiyoso dan Tutuko (2009: 7) menyatakan bahwa kearifan lokal merupakan perilaku positif manusia dalam berhubungan dengan alam dan lingkungan sekitarnya, yang dapat bersumber dari nilai agama, adat-istiadat, petuah nenek moyang atau budaya setempat, yang terbangun secara alamiah dalam suatu komunitas masyarakat untuk beradaptasi selaras dengan lingkungan sekitarnya. Tingginya perkembangan ilmu pengetahuan dan teknologi (IPTEK) membuat masyarakat Indonesia sudah mulai melupakan identitas kebudayaannya. Ini terlihat dari pola tingkah prilaku yang menyimpang dalam berbagai aspek kehidupan, seperti berbahasa, berpakaian, tingkat kriminalitas dan lain sebagainya. Hal ini berdampak pada rusaknya kondisi lingkungan akibat aktivitas manusia. Sehingga nilai-nilai kebudayaan di Indonesia harus dipertahankan dan diidentifikasi sebagai warisan nilai bangsa Indonesia untuk hidup selaras dengan lingkungan, salah satunya terdapat di Kampung Adat Dukuh yang ada di Kabupaten Garut.

Kampung Dukuh adalah suatu kampung adat yang berada di Desa Cikelet, Kecamatan Cikelet, Kabupaten Garut, Provinsi Jawa Barat. Nilai kebudayaan yang ada di kampung adat ini berasal dari akulturasi nilai-nilai religius dari ajaran agama Islam. Sebagai bentuk kearifan lokal masyarakat hidup selaras dan seimbang dengan lingkungannya. Artikel ini bertujuan membahas nilai-nilai kebudayaan di Kampung Adat Dukuh sebagai bentuk kearifan lokal dalam hidup serasi dan selaras dengan lingkungan.

\section{METODE PENELITIAN}

Artikel ini membahas nilai-nilai kebudayaan di Kampung Adat Dukuh sebagai bentuk kearifan lokal dalam hidup selaras dengan lingkungan, menggunakan pendekatan kualitatif dengan metode penelitian deskriptif seperti dinyatakan Ahman Sya (2011: 49) metode ini dipakai untuk mengkaji dan menganalisis berbagai data, gejala, dan peristiwa yang ada dan terjadi saling berinteraksi pada ruang permukaan bumi. Interelasi keruangan gejala dalam konteks hubungan manusia dengan alam lingkungan, adalah ciri pokok dalam aplikasi metode ini. Sedangkan mengenai pendekatan kualitatif, Sukmadinata (2015: 60) bahwa penelitian kualitatif ditujukan untuk mendeskripsikan 
dan menganalisis fenomena, peristiwa, aktivitas sosial, sikap, kepercayaan, persepsi, pemikiran orang secara individual maupun kelompok.

Teknik pengumpulan data yang digunakan dalam penelitian ini berupa wawancara, observasi, studi dokumenter, dan studi literatur untuk mengetahui nilai-nilai kebudayaan yang ada di kampung adat tersebut dan bagaimana nilai kebudayaan tersebut masih bertahan. Subjek dalam penelitian adalah narasumber (informan) yang mengetahui dan memahami secara mendalam dan menyeluruh mengenai objek yang diteliti.

Adapun sampel dalam penelitian ini dilakukan dengan teknik snow ball sampling yang artinya peneliti melakukan pencarian informasi dengan cara menentukan informan yang dipilih sesuai dengan kebutuhan informasi yang akan diteliti, tetapi tidak menutup kemungkinan untuk menambahkan informan lain untuk mendapatkan kelengkapan informasi. Informan dalam penelitian ini adalah Juru Kunci Kampung Dukuh, pemerintahan setempat dan masyarakat Kampung Dukuh.

\section{HASIL DAN PEMBAHASAN}

\section{Nilai Kebudayaan Kampung Adat Dukuh} dalam Hidup Selarah dengan Lingkungan

Secara geografis Kampung Dukuh terletak di Kabupaten Garut bagian selatan, yang merupakan daerah perbukitan dengan ketinggian 390 Mdpl. Kampung Dukuh memiliki luas wilayah sekitar $13 \mathrm{Ha}$ yang terdiri lahan pemukiman penduduk seluas $5 \mathrm{Ha}$ dan sisanya merupakan hutan tutupan dan hutan larangan. Wilayah Kampung Dukuh dibagi menjadi dua yaitu Dukuh Tonggoh (Dukuh Dalam) dan Dukuh Landeuh (Dukuh Luar). Secara etimologi nama Kampung Dukuh berasal dari kata padukuhan, dukuh yang dalam Bahasa Sunda berarti calik atau duduk. Jadi dukuh merupakan tempat bermukim atau tempat tinggal.

Ada juga yang mengartikan dukuh dengan teguh, kukuh, patuh, dan tukuh yang bermakna kuat, tegas dan teguh dalam mempertahankan apa yang menjadi miliknya yaitu sangat patuh dalam menjalankan tradisi warisan nenek moyangnya. Selain Dukuh Dalam dan Dukuh Luar, ada Kampung Bangkelung yang merupakan bagian dari Kampung Dukuh Luar. Nama Kampung Bangkelung sendiri berasal dari kata bangkelang (Bahasa Sunda) yang artinya adalah pembangkang. Dikatakan pembangkang karena orang-orang tersebut tidak mengikuti aturan-aturan adat sebagaimana yang terdapat di Kampung Dukuh Dalam.

Wilayah Kampung Dukuh Luar dan wilayah Kampung Bangkelung yang berada di luar areal karomah Syekh Abdul Jalil menyebabkan aturan-aturan adat seperti halnya di Kampung Dukuh Dalam sudah sedikit longgar. Kehidupan sosial budaya penduduknya sudah tercampuri oleh budayabudaya luar. Aturan- aturan adat seperti yang terdapat di Kampung Dukuh Dalam sudah nampak tidak dilaksanakan oleh masyarakat.

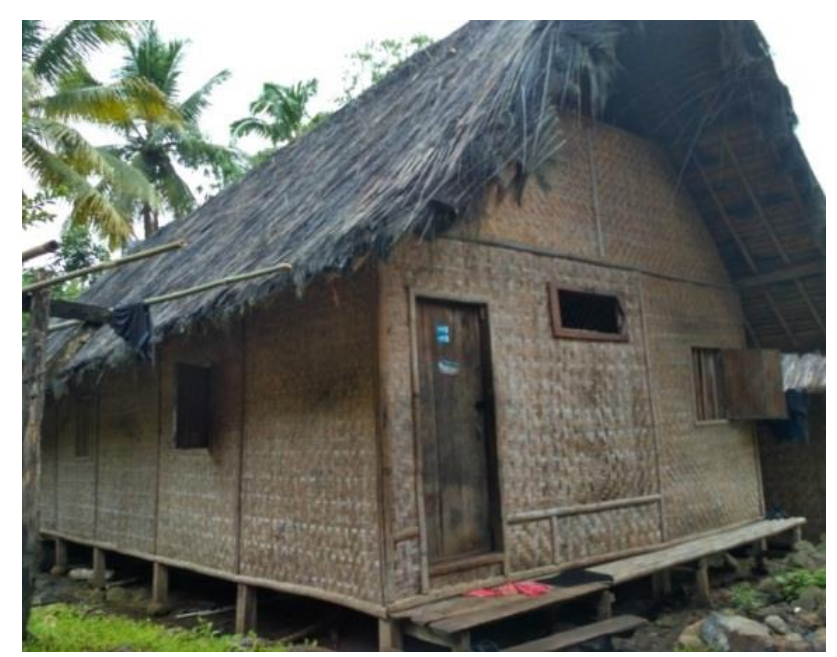

Gambar 1. Pagar Pembatas dan Rumah di Kampung Adat

(Sumber: Dokumentasi Penelitian, 2018) 
Lima fungsi adat dalam mengatur alam yaitu berkaitan dengan pembagian jenis tanah dalam hal fungsi dan penggunannya. Pembagian jenis tanah adat yang ada di Kampung Dukuh yaitu sebagai berikut :

1. Tanah Tutupan. Tanah tutupan yaitu gunung yang berfungsi sebagai sumber kehidupan. Gunung merupakan sumber bahan pokok karena dapat menghasilkan mata air yang memiliki manfaat sangat besar bagi manusia. Air memiliki peranan yang cukup penting dalam kehidupan manusia, seperti untuk menumbuhkan tanaman, dibutuhkan untuk kegiatan keagamaan, serta dibutuhkan untuk minum dan memasak. Atas dasar itu, masyarakat Kampung Dukuh begitu menjaga Gunung Dukuh yang berada di sebelah utara kampung karena merupakan lokasi dari sumber mata air yang masyarakat Kampung Dukuh butuhkan. Masyarakat Kampung Dukuh menjaga sumber mata air yang mereka miliki dengan cara tidak menebang pohon sembarangan yang terdapat di Gunung Dukuh

2. Tanah Titipan. Tanah titipan merupakan tanah yang terdapat dalam wasiat leluhur Kampung Dukuh. Tanah titipan di Kampung Dukuh terdiri dari tanah yang disebut dengan tanah awisan. Tanah awisan tersebut terdiri dari tanah awisan Arab yang lokasinya berada di sebelah barat rumah kuncen, tanah awisan Dukuh lokasinya berada di sekitar Kampung Dukuh Dalam, tanah awisan Bangkelung berada di sebelah barat daya Kampung Dukuh, tanah awisan Sukapura lokasinya berada di sebelah barat Kampung Dukuh, dan tanah awisan Sumedang lokasinya berada di sebelah timur Kampung Dukuh.

3. Tanah Larangan. Tanah larangan merupakan tanah yang dianggap suci dan sakral sehingga memiliki batasan-batasan tertentu dalam bertindak sesuai dengan aturan-aturan adat yang wajib untuk dipatuhi. Di Kampung Dukuh terdapat tiga tanah larangan, dan setiap tanah larangan tersebut dibatasi oleh pagar yang terbuat dari awi (bambu). Ketiga tanah larangan tersebut adalah : tanah larangan kampung, tanah larangan makom dan tanah larangan hutan.
4. Tanah Garapan. Tanah garapan di Kampung Dukuh merupakan tanah yang dikelola oleh masyarakat Kampung Dukuh dalam upaya untuk memenuhi kebutuhan hidupnya sehari-hari. Tanah garapan di Kampung Dukuh meliputi persawahan dan perkebunan.

5. Tanah Cadangan. Tanah cadangan di Kampung Dukuh merupakan tanah yang berfungsi untuk keberlangsungan hidup penerus Kampung Dukuh di masa depan. Tanah cadangan Kampung Dukuh meliputi wilayah hutan cadangan yang sekarang ini dikelola oleh pihak perhutani. Masyarakat Kampung Dukuh berharap supaya kedepannya bisa mendapatkan haknya kembali mengenai kawasan hutan yang sekarang ini dikelola oleh pihak perhutani tersebut. Tanah cadangan Kampung Dukuh merupakan tanah warisan dari para leluhur Kampung Dukuh yang harus dijaga kelestariaannya sehingga dapat berguna dan dimanfaatkan oleh generasi penerus Kampung Dukuh di masa yang akan datang.

Kampung Dukuh merupakan kesatuan pemukiman yang mengelompok dengan kondisi lahan yang relatif miring. Pada kondisi lahan yang miring dibuat sengkedan, setiap sengkedan terdapat puluhan rumah yang berjajar secara bertingkat. Pada setiap tingkatan terdapat beberapa deretan rumah yang membujur dari arah timur ke arah barat. Bentuk rumah yang berbaris serta menghadap kearah barat merupakan sebuah siloka (Bahasa Sunda yang berarti tanda atau simbol) bahwa dalam beribadah khususnya shalat harus dilakukan secara berjamaah, dan menghadap ke arah barat merupakan perwujudan dari arah kita shalat yaitu menghadap kiblat (Ka'bah di Mekah).

Sampai sekarang ini masyarakat Kampung Dukuh Dalam masih mempertahankan bentuk rumah tradisional yang mereka miliki, karena itu merupakan warisan dari leluhur Kampung Dukuh yang harus dijaga dan dilestarikan.

Rumah masyarakat Kampung Dukuh Dalam sekarang ini berjumlah 26 suhunan (Atap), dengan ditambah 1 bangunan masjid, 1 madrasah, 1 bale adat, dan 1 bumi alit. Sebelum terjadi kebakaran pada tahun 2011 
jumlah rumah di Kampung Dukuh Dalam ada 40 suhunan. Namun akibat kebakaran tersebut seluruh rumah hancur dan rata dengan tanah, dan pada akhirnya jumlah warga Kampung
Dukuh Dalam mengalami penurunan karena ada yang pindah ke daerah lain dengan alasan takut kejadian kebakaran tersebut terulang kembali.

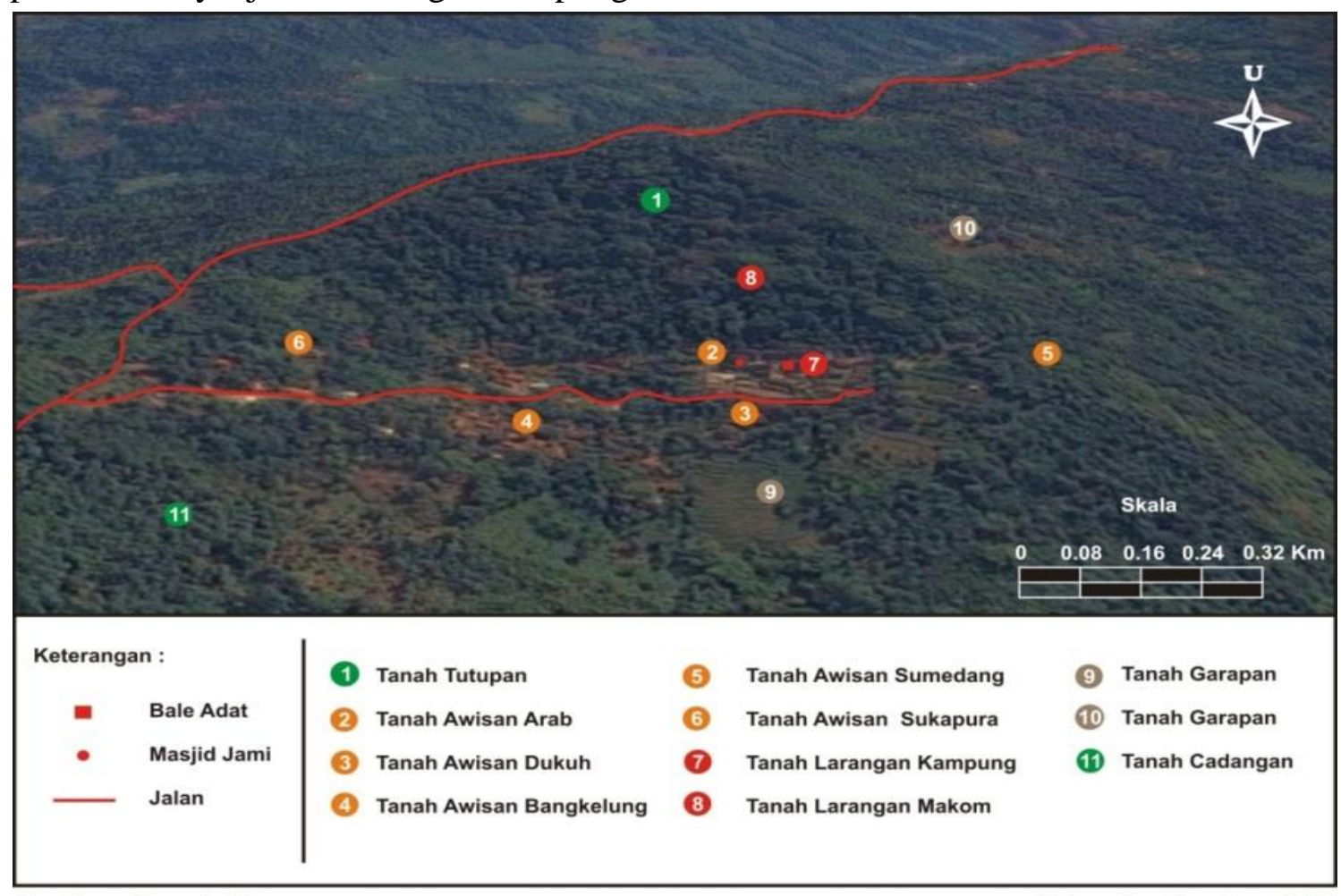

Sumber : Google Map

Tahun Pembuatan : 2017

(Sumber: Asgar, 2017: 84)

Gambar 2. Peta Pembagian Tanah Adat Kampung Dukuh

Bentuk fisik rumah di Kampung Dukuh Dalam seluruhnya masih sangat tradisional, yaitu berupa rumah panggung persegi yang disangga oleh tiang-tiang yang berdiri pada tatapakan (alas/tumpuan) batu, serta terdapatnya kolong rumah yang digunakan untuk menyimpan kayu bakar, hewan ternak, dan ada juga yang dibiarkan kosong. Karena bentuk rumah berupa panggung maka dibuatlah golodog (teras mini) yang ditempatkan di depan pintu rumah. Golodog berfungsi sebagai tangga dan sebagai tempat duduk di depan rumah.

Material yang digunakan untuk membangun rumah yaitu harus menggunakan bahan-bahan dari alam seperti awi (bambu), ijuk, kayu, dan batu. Bambu digunakan untuk bilik, golodog, dan tiang, kayu digunakan untuk tiang, ijuk digunakan untuk atap, sedangkan batu digunakan untuk tatapakan atau dasar dari tiang penyangga rumah. Aturan adat menyatakan bahwa rumah tidak boleh terbuat dari tembok, atap tidak boleh menggunakan genteng atau asbes, dan jendela tidak boleh menggunakan kaca. Ukuran rumah di Kampung Dukuh Dalam berbeda-beda karena disesuaikan dengan kondisi lahan yang ada. Namun apabila dirata-ratakan rumah di Kampung Dukuh Dalam memiliki ukuran 8 x 5 meter.

Antropolog C. Kluckhohn di dalam karyanya yang berjudul Universal Categories of Culture (Soekanto, 2012: 154) telah menguraikan Cultural Universals menjadi tujuh unsur kebudayaan, yaitu: bahasa, sistem pengetahuan, sistem kemasyarakatan, peralatan dan perlengkapan hidup manusia (teknologi), mata pencaharian hidup dan sistem-sistem ekonomi, sistem kepercayaaan (religi), dan kesenian. Unsur budaya universal yang masih bertahan di Kampung Dukuh akan dijelaskan sebagai berikut:

1. Bahasa. Masyarakat Kampung Dukuh seluruhnya merupakan orang Sunda sehingga dalam kehidupan sehari-hari mereka berkomunikasi menggunakan bahasa Sunda. Bahasa Sunda yang digunakan oleh masyarakat Kampung 
Dukuh adalah bahasa Sunda lemes (halus) dan bahasa Sunda loma (biasa). Bahasa Sunda halus digunakan ketika mereka berkomunikasi dengan orang yang lebih tua atau dihormati. Selain itu ketika masyarakat Kampung Dukuh berkomunikasi dengan pengunjung atau tamu yang sama-sama menggunakan bahasa Sunda mereka menggunakan bahasa Sunda halus.

2. Sistem Pengetahuan. Masyarakat Kampung Dukuh sebagai masyarakat adat memiliki sistem pengetahuan yang bersumber dari pengalaman dan aturanaturan leluhur Kampung Dukuh yang diwariskan secara turun temurun. Aturanaturan tersebut menjadi sebuah pengetahuan dan dijadikan pedoman oleh masyarakat Kampung Dukuh dalam menjalani aktifitas sehari-hari.

3. Sistem Kemasyarakatan (Organisasi Sosial). Masyarakat Kampung Dukuh memiliki sistem kemasyarakatan atau organisasi sosial yang berbeda dengan kampung lain pada umumnya. Sebagai kampung adat, Kampung Dukuh tidak hanya memiliki sistem kemasyarakatan atau organisasi sosial yang bersifat formal saja, tetapi juga memiliki organisasi sosial yang bersifat non formal. Sistem organisasi sosial yang bersifat formal yaitu bahwa di Kampung Dukuh terdapat aparatur pemerintah yang terdiri dari empat RT dan satu RW, sedangkan sistem organisasi sosial yang bersifat non formal bahwa di Kampung Dukuh terdapat seorang Kuncen yang berperan sebagai pemimpin adat.

4. Teknologi dan Peralatan. Masyarakat Kampung Dukuh terutama Dukuh Dalam sampai saat ini masih menggunakan teknologi dan peralatan yang bersifat tradisional. Masyarakat Kampung Dukuh Dalam masih memegang teguh aturan adat yang tidak memperbolehkan alat-alat modern masuk ke areal kampung. Listrik beserta alat-alat elektronik dilarang masuk ke areal kampung, karena mereka meyakini bahwasannya alat-alat elektronik tersebut selain memiliki manfaat tetapi banyak mudharatnya dan dapat mengganggu kehidupan dalam beribadah.

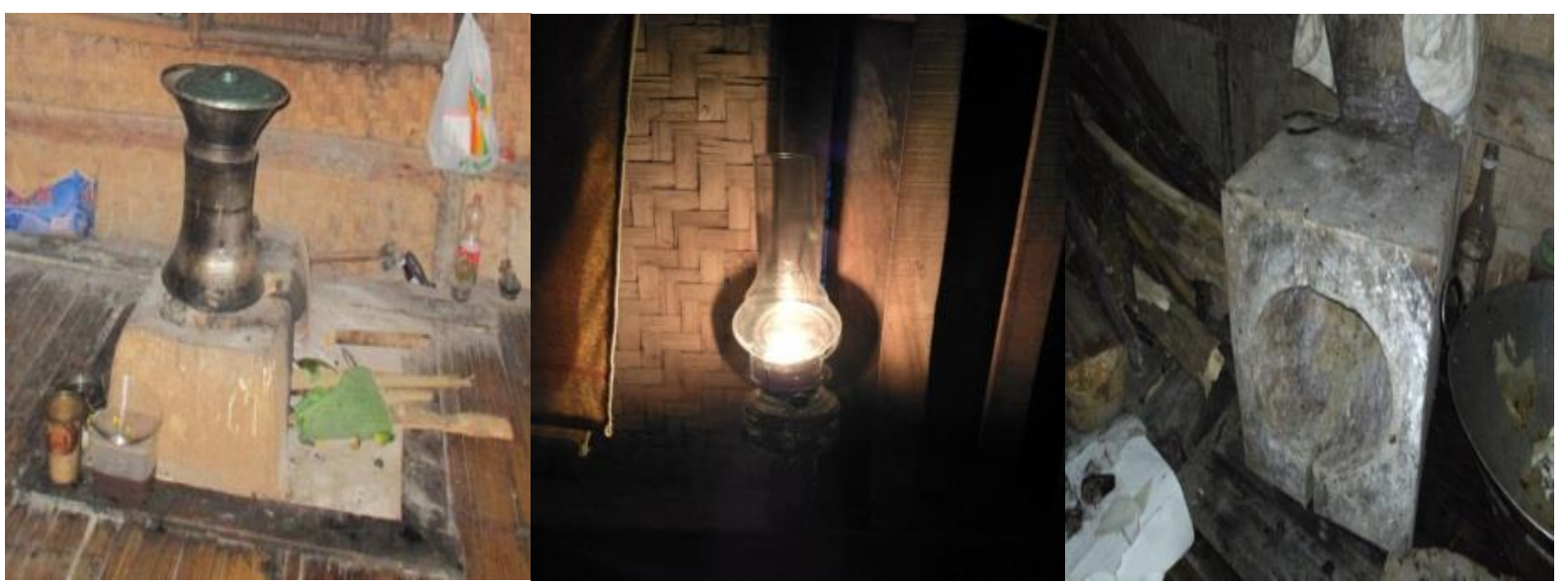

Sumber: Dokumtasi penelitian, 2017

Gambar 3. Peralatan hidup di Kampung Adat Dukuh (seeng, cempor, jubleg)

5. Sistem Mata Pencaharian. Sistem mata pencaharian hidup merupakan produk dari manusia sebagai homo economicus menjadikan tingkat kehidupan manusia secara umum terus meningkat (Widyosiswoyo, 2004:34). Sejalan dengan pendapat tersebut manusia melakukan berbagai usaha supaya mereka dapat menghasilkan sesuatu yang dapat menunjang keberlangsungan hidupnya. Masyarakat Kampung Dukuh memanfaatkan sumberdaya alam yang ada untuk memenuhi kebutuhan sehari-hari. Sebagian besar masyarakat Kampung Dukuh bekerja sebagai petani. Dalam pengelolaan pertanian sawah, petani masih menggunakan alat-alat tradisional seperti wuluku dan pacul.

6. Sistem Kepercayaan. Masyarakat Kampung Dukuh seluruhnya menganut ajaran agama Islam. Mereka merupakan masyarakat yang taat dalam menjalankan 
ibadah. Sebagaimana umat Islam pada umumnya, mereka menjalankan ibadah seperti shalat lima waktu, melaksanakan pengajian rutin, berpuasa di bulan ramadhan, melaksanakan zakat dan melaksanakan qurban. Pada masyarakat Kampung Dukuh Dalam ada beberapa nilai ajaran yang sampai sekarang ini masih dilaksanakan dan dipertahankan.

7. Kesenian. Kesenian Terbang Sejak merupakan sebuah kesenian masyarakat Kampung Dukuh sebagai kesenian karuhun yang telah ada dari zaman dahulu. Kesenian Terbang Sejak tersebut manjelaskan bahwa kesenian ini sudah hidup dan berkembang sejak abad ke 17 . Kesenian Terbang Sejak biasanya dipentaskan pada saat acara pernikahan dan acara khitanan.

\section{Upaya Masyarakat Kampung Adat Dukuh} Mempertahankan Nilai Kebudayaannya

Kampung Dukuh merupakan salah satu kampung adat yang memiliki aturan-aturan khusus yang harus dipatuhi dan dilaksanakan oleh masyarakat khususnya yang bermukim di dalam areal tanah larangan Kampung Dukuh Dalam. Aturan-aturan tersebut telah lama hidup sehingga menjadi ciri khas dari kehidupan yang ada pada masyarakat Kampung Dukuh Dalam. Masyarakat mempertahankan nilai budaya yang terkandung dalam aturan adat dengan beberapa upaya, diantaranya:

1. Tidak berdagang di lingkungan Kampung. Di dalam agama Islam yang dianut masyarakat Kampung Dukuh Dalam memang tidak ada keterangan yang menyatakan tentang larangan dalam berdagang selama kegiatan tersebut dilakukan sesuai dengan kaidah-kaidah dan ketentuan yang telah ditetapkan oleh Allah. Larangan berdagang berlaku bagi masyarakat yang bermukim di dalam areal Kampung Dukuh Dalam. Kondisi tersebut bertujuan supaya tidak menimbulkan kecemburuan sosial dan mencegah timbulnya rasa iri hati sehingga keharmonisan diantara sesama masyarakat Kampung Dukuh Dalam tetap terjaga. Bukti ditaatinya larangan tersebut adalah tidak ditemukannya warung dengan aktifitas jual beli yang biasa dilakukan masyarakat umum di daerah lain.

2. Tidak menggunakan aliran listrik dan barang elektronik. Kampung Dukuh terdapat aturan adat yang menyatakan bahwa listrik beserta alat-alat elektronik tidak boleh masuk kedalam areal Kampung Dukuh Dalam. Larangan terhadap adanya listrik sampai sekarang ini masih tetap dipertahankan dan dilaksanakan oleh masyarakat Kampung Dukuh Dalam. Masyarakat Kampung Dukuh Dalam percaya bahwa alat-alat elektronik selain memiliki manfaat tetapi juga memiliki banyak kemudharatan yang dapat mengganggu tingkat ketakwaan mereka dalam beribadah.

3. Tidak Menjadi Pegawai Negeri Sipil (PNS). Aturan adat mengenai larangan menjadi Pegawai Negeri Sipil (PNS) didasarkan pada sejarah tentang Syekh Abdul Jalil yang mengundurkan diri dari jabatannya sebagai penghulu atau pemuka agama di kerajaan Sumedang. Syekh Abdul Jalil mengundurkan diri karena bupati Sumedang pada saat itu pangeran Rangga Gempol II mengkhianati janjinya terhadap Syekh Abdul Jalil dengan melanggar syara yaitu melakukan pembunuhan terhadap utusan yang berasal dari pemerintahan kerajaan Banten.

4. Tidak Membangun Rumah Mewah Melebihi dari Tetangga. Larangan membangun rumah mewah melebihi tetangga memiliki tujuannya supaya adanya keserasian antara sesama warga Kampung Dukuh Dalam sehingga tidak menimbulkan adanya persaingan yang berhubungan dengan perkara dunia, menciptakan kehidupan yang sama rata sehingga ikatan kekeluargaan dan kegotongroyongan masih tetap terjaga.

5. Mempertahankan Nilai Budaya melalui Pendidikan. Masyarakat Kampung Dukuh memiliki anggapan bahwa pendidikan tidak hanya diperoleh dari pendidikan formal saja, tetapi pendidikan non formal khususnya pendidikan agama merupakan suatu yang lebih penting sebagai bekal dalam hidup. Pendidikan agama masyarakat Kampung Dukuh diperoleh melalui kegiatan pengajian rutin yang 
selalu dilaksanakan oleh masyarakat Kampung Dukuh. Melalui pengajian rutin secara tidak langsung dapat membuat adat dan budaya yang mereka miliki dapat bertahan sampai sekarang ini karena dilandasi dengan ketakwaan masyarakat Kampung Dukuh dalam beribadah kepada Allah.

6. Pewarisan Kebudayaan. Bentuk pewarisan kebudayaan yang dilakukan oleh masyarakat Kampung Dukuh Dalam merupakan bentuk pewarisan yang bersifat vertikal, hal ini sejalan dengan apa yang disampaikan oleh Warsito (2012: 59) bahwa pewarisan yang bersifat vertikal ialah pewarisan kebudayaan oleh generasi tua kepada generasi muda atau dari orang tua kepada anak-anaknya atau cucucucunya. Pewarisan budaya tersebut dimulai dengan memberi contoh dan anak - anaknya mengikuti apa yang orang tua lakukan. Ketika seorang anak melanggar aturan, maka orang tua akan mengingatkan anaknya bahwa apa yang dia lakukan tersebut merupakan pamali atau sesuatu yang dilarang oleh adat dan apabila dilanggar akan mendapatkan suatu musibah tertentu.

\section{SIMPULAN}

Berdasarkan hasil penelitian dapat disimpulkan bahwa terdapat nilai kebudayaan sebagai bentuk kearifan lokal di Kampung adat dukuh yang meliputi 1) Pembagian jenis tanah adat menjadi berupa tanah tutupan, tanah titipan, tanah larangan dan tanah garapan; 2) Bentuk rumah tinggal masyarakat Kampung Adat Dukuh masih sederhana dan hanya menggunakan material kayu dan bambu serta tanpa toilet atau kamar mandi dikarenakan kondisi lahannya yang tidak memungkinkan untuk sistem drainase dan 3) Unsur Budaya Universal yang masih dipertahankan meliputi: bahasa yang digunakan yaitu Bahasa Sunda, agama yang dianut seluruh masyarakat Kampung Dukuh adalah adalah Islam, mata pencaharian mayoritas bersumber dari alam, peralatan hidup masih tradisional.

Berbagai nilai kebudayaan tersebut dipertahankan dengan cara 1) tidak melakukan aktivitas berdagang di likngkungan Kampung Dukuh Dalam, 2) menolak memanfaatkan aliran listrik serta memiliki dan menggunakan alat elektronik demi menjaga kekhusyuan dalam beribadah, 3) tidak menjadi Pegawai Negeri Sipil dan 4) tetap hidup dalam kesederhanaan yang ditunjukkan dengan tidak membangun rumah mewah melebihi tetangga, serta mempertahankan nilai budaya dengan cara mewariskannya kepada generasi muda melalui pendidikan.

\section{REKOMENDASI}

Kerusakan lingkungan yang berdampak negatif manusia pada dasarnya dapat dicegah melalui nilai kebudayaan, salah satunya di Kampung Adat Dukuh yang perlu dipertahankan. Perlu peran aktif pemerintah dan masyarakat adat sendiri untuk mempertahankan dan menularkan nilai positif tersebut. Sebaiknya menjadi inventarisasi pemerintah dan masyarakat sekitar sebagai peninggalan non kebendaan.

\section{DAFTAR PUSTAKA}

Ahman Sya, H.M. (2011). Pengantar Geografi. Bandung: LPPM Universitas Bina Sarana Informatika (BSI)

Asgar, Saepul. (2017). Kearifan lokal masyarakat Kampung Dukuh di Desa Ciroyom Kecamatan Cikelet Kabupaten Garut. Jurusan Pendidikan Geografi FKIP Universitas SiliwangiSkripsi.Tidak Diterbitkan

Harsojo. (1984). Pengantar Antropologi. Bandung : Penerbit Binacipta

Koentjaraningrat. 1993. Kebudayaan Mentalitas dan Pembangunan. Jakarta : PT Gramedia Pustaka Indah

Sartini. (2004). Menggali Kearifan Lokal Nusantara. Dalam Jurnal Filsafat. Jilid 37. Nomor 2. Halaman 111-120.

Soekanto, Soekanto. dan Sulistyowati, Budi. 2013. Sosiologi Suatu Pengantar. Jakarta : PT Raja Grapindo Persada

Sukmadinata, Nana Syaodih. (2015). Metode Penelitian Pendidikan. Bandung: PT. Remaja Rosdakarya. 
Warsito, H.R. (2012). Antropologi Budaya. Yogyakarta : Penerbit Ombak.

Wikantiyoso, Respati. dan Tutuko, Pindo. 2009. Kearifan Lokal dalam Perencanaan Dan perancangan Kota; untuk Mewujudkan Arsitektur Kota yang Berkelanjutan. Malang: Grup Konservasi Arsitektur dan Kota.

Widyosiswoyo, S. (2004). Ilmu Budaya Dasar.

Bogor Selatan : Penerbit Ghalia Indonesia. 